\title{
Impacts of Bilingual Education on Secondary School Grades, Attendance, Retentions and Drop-out
}

\author{
Herman Curiel \\ James A. Rosenthal \\ Herbert G. RicheK \\ University of Oklahoma
}

Junior high and high school academic performance of two groups of students were compared in a quasi-experimental study. The experimental group students $(N=86)$ had received one or more years of bilingual instruction at the elementary level while the control group students $(N=90)$ had not participated in an elementary bilingual program. While differences in grade-point average (GPA) and absenteeism were small, the bilinguals were less likely to drop-out and experienced fewer retentions. Secondary analyses focused on the relationships within the experimental group between number of years enrolled in bilingual programs and secondary school outcomes. The relationships of number of years to absenteeism and to retention were quite weak. Important relationships between number of years and GPA and between number of years and drop-out were observed. As number of years increased, mean GPA in 7th, 8th and 9th grades increased and the probability of drop-out decreased.

The merits of bilingual education have been debated since the passage of the Bilingual Education Act of 1968 and before then. While it is true that political considerations are at the center of this debate, bilingual education will ultimately flourish or decline on the basis of the degree to which the programs are able to demonstrate short and long term gains for language minority pupils and demonstrate this to the public.

Requests for reprints should be sent to Herman Curiel, Ph.D., Rhyne Hall, University of Oklahoma, School of Social Work, Norman, OK. 
Various researchers have investigated the effects of bilingualism (Peal \& Lambert, 1962) and bilingual instruction (Cumins, 1981; Leyba, 1978; Saldate, Mishra \& Medina, 1985; Barclay, 1983; Troike, 1978; Croft \& Franco, 1983; Curiel, Stenning \& Stenning, 1979; Powers \& Rossman, 1984) upon achievement in various areas. A recent meta-analysis of selected studies on the efficacy of bilingual education (Willig, 1985) revealed small to moderate differences favoring bilingual participants on selected academic achievement tests and on some attitudinal measures. Although the findings of such studies vary, it can be safely concluded that contrary to the formerly prevailing view, bilingualism does not retard children's language development and achievement and has been shown to have favorable effects.

Despite some research supporting beneficial effects of bilingual instruction, the widely publicized study undertaken by the American Institutes of Research (AIR) (Danoff, Coles, McLaughlin, \& Reynolds, 1977a, 1977b, 1978a, 1978b) to assess the impact of the federally funded bilingual education programs concluded that the programs were ineffective and that the participants' academic achievement gains in reading and mathematics were not significantly different from nonparticipants' gains. A number of longitudinal studies are now beginning to appear in the literature that indicate positive long-term results from early exposure to bilingual schooling (Leyba, 1978; Powers \& Rossman, 1984; Saldate et al., 1985; Flores, 1981). These studies address cognitive gains in reading and math skills. Although it is assumed that bilingual education in early grades will have a positive effect on reducing the rate of retentions and school drop-outs, no studies were found that address these variables which are the focus of this study.

Bilingual-bicultural education is a comprehensive educational approach that involves more than just imparting English skills (Anderson \& Boyer, 1970). Bilingual education is best defined as academic instruction in two languages, that is, the child's native language and English (Cordasco, 1983). All bilingual-bicultural education programs include consideration for the students' cultural heritage and show a common concern for student development in two languages and cognitive achievement in all subject areas. By design, bilingual-bicultural programs are normally placed in elementary school $\mathrm{K}-6$ th grades. The majority of programs were found in the lower grades (U.S. Department of Education, Annual Report, 1984).

The goals of bilingual-bicultural education programs are con- 
sistent with the general goals of education: to produce a citizen who is a contributing member of society. The ultimate and primary goal is for students to learn English. The mutual emphasis is on helping learners become literate in their native language. The rationale is that this approach to learning capitalizes on previous learning, minimizes the cognitive dissonance and sense of anomie that the non-English speaker initially experiences in the regular English only curriculum. Bilingual-bicultural programs, as conceptualized in the 1967 Title VII of the Elementary and Secondary Act, are considered compensatory programs (i.e., they are designed to facilitate transition from a "special treatment program" to the regular English instruction program). The 1984 amendments to the Bilingual Education Act, Public Law 98-511, affirms the time expectations of the title VII program by the use of the term transitional bilingual education.

The present study examines the long-term impacts of one program that was designed as a transitional program for children in elementary grades. Students were placed in the program for varied periods at grades $\mathrm{K}$ through sixth. In transitional compensatory oriented bilingual programs the objective is to use the students' native language as a beginning foundation to facilitate literacy in the learners' native language and promote gradual phasing in of English as the students' knowledge of first language is sufficient to serve as a base for the new language. The literature indicates that early successful learning experiences are more predictable and likely to become a pattern when the instruction builds on the learners' native language (Cummins, 1977; Fradd, 1982). The ultimate goal is to graduate the student to an all English curriculum.

The bilingual education program of the Houston Independent School District (HISD) began in 1967 in four elementary and two secondary schools where nearly $100 \%$ of the students were Mexican American. Enrollment was voluntary, with preference given to children of limited English-speaking ability who came from low-income families. During the first five years, the program enrollment grew from 585 to 1,550 students in K-12 (Cortez \& Say, 1974). The program was one of four selected from 175 United States programs reviewed and cited for exemplary status. Recognition was based on demonstrated positive educational outcomes for students in achieving significant gains in English language skills as well as in content areas taught in the native language. The bilingual program teacher-pupil ratio was twenty- 
five to one compared to twenty-nine to one in the regular classrooms. Students entered the bilingual program at varied levels and for different periods of time.

This investigation is a follow-up of previous work by the senior author (Curiel et al., 1979). Curiel found that students exposed to bilingual programming in elementary school maintained higher elementary grade point averages (GPAs) than a non-randomly selected control group. The controls scored higher in sixth grade on three reading measures of the Iowa Test of Basic Skills. No statistically significant differences were observed in seventh grade in GPA, and self-esteem. Control group members did score higher on one of three seventh-grade English reading measures.

This study follows Curiel's (1979) experimental and control groups through the first semester of eleventh grade. Primary outcome measures are GPA, attendance, retention, and drop-out. In addition to the comparison of outcomes for the experimental and control groups, a second series of analyses examines the relationship of length of exposure to bilingual programming and outcomes.

\section{METHODS}

A quasi-experimental design was used to compare two groups of Mexican American students who had been followed for a period of ten years since enrollment in elementary school. All children in the study were selected from the population of seventh-grade students attending two Houston area junior highs in 1977. Children in special education classes were excluded. The experimental group $(N=86)$ had received one or more years of instruction in an elementary bilingual program. These children were initially subjects in Cortez and Say's (1974) bilingual study and were later subjects in the Curiel et al. (1979) study. The control group $(N=90)$ had received instruction in a traditional elementary program where all subject matter was presented in English. Eighteen (20\%) of the control group children had been participants in the original Cortez and Say study while the remainder were an additional random sample selected from one of the two junior highs.

Previous investigations have shown a relationship between school-related variables and academic achievement (Coleman et al., 1966). On balance, the experimental and control groups were well matched on socio-demographic variables potentially associated with academic performance. Forty-four percent (38 of 86) of 
experimental group children versus $46.7 \%$ (42 of 90 ) were female. Among experimentals, $41.2 \%$ (35 of 85 ) of fathers and $37.6 \%$ (32 of 85) of mothers were born in Mexico. Among controls these percentages were $28.2 \%$ (24 of 85 ) for fathers and $27.6 \%$ (24 of 87) for mothers. As subjects completed seventh grade, $22.1 \%$ (22 of 86) of experimentals and $34.4 \%$ (31 of 90) of controls were in single-parent households. In the experimental group, $57.0 \%$ (49 of 86) children reported that there were 50 or more books in the home; 57.8 of control subjects so reported. None of the above differences are statistically significant. The mean educational levels of parents in the two groups were quite similar (experimental group: father, 8.0 years, mother, 8.1 years; control group: father 8.2 years, mother, 7.9 years). Father's occupation was grouped into one of four categories (skilled, semi-skilled, unskilled, other). Chi-square analysis were not significant, $\mathrm{X}^{2}(3)=7.00, p>.05$.

While the overall pattern was one of similarity between groups, several important differences emerged. Experimental group children were younger than control children, $\bar{X}=12.94$ years at the end of seventh grade for experimentals, $\bar{X}=13.24$ for controls, $\mathrm{t}(173)=2.72, p<.01$. This age difference reflected the more frequent retention of students who had not been in the bilingual program. Control group students were retained a mean of 0.38 times in elementary school as compared to a mean of 0.13 times for the bilingual students, $\mathrm{t}(165)=3.68, p<.001$. Finally, experimental subjects more frequently reported Spanish as the primary language in the family home. Among these subjects, $15.1 \%$ reported Spanish, $17.9 \%$ reported English, and $67.4 \%$ reported that both Spanish and English were used. Among the 90 control group subjects, $6.7 \%$ reported Spanish, $25.6 \%$ reported English and $67.8 \%$ reported both languages. This ordinal trend reached significance, Kendall's Tau $\mathrm{B}=.141, p<.05$.

One possible weakness in the design relates to the junior highs which students attended. While $91.9 \%$ (79 of 86) of experimentals attended junior high \#1 (arbitrarily designated), only $20 \%$ (18 of 90). control group members attended this school. The relationship of school attended and study group was statistically significant, $\mathrm{X}^{2}$ $(1)=91.8, p<.001$, and may have affected some comparisons. The within-group analyses of the impact of length of time in bilingual programming is not affected by this issue. 
Table 1

Drop-outs in Experimental and Control Groups

\begin{tabular}{lccccc}
\hline & \multicolumn{3}{c}{ Experimental Group } & \multicolumn{3}{c}{ Control Group } \\
$\begin{array}{l}\text { Level at time } \\
\text { of drop-out }\end{array}$ & $\%$ & $N$ & $\%$ & $N$ & $X^{2}$ \\
\hline Junior High & 8.1 & 86 & $25.8 \%$ & 89 & $8.44^{\star}$ \\
$\begin{array}{l}\text { High School } \\
\text { High School or }\end{array}$ & 16.7 & 78 & 22.2 & 63 & 0.38 \\
$\quad$ Junior High & 23.5 & 85 & 43.0 & 86 & $7.31^{*}$ \\
\hline
\end{tabular}

Note. Junior high totals include all drop-outs prior to end of ninth grade. High school totals include drop-outs through the first semester of eleventh grade. Students who dropped out in junior high were excluded from high school analysis.

${ }^{\star} p<.01$

\section{Findings}

\section{Experimental Versus Control Group Analyses}

The results for GPA and school attendance were examined first. While differences on these two measures did not attain statistical significance, the pattern of findings favors the bilingual treatment students; in a total of eight comparisons they out-performed their control group counterparts on all comparisons. Experimental group children also experienced lower retention rates in junior high. Of the 86 subjects, 82 were not retained in seventh, eighth or ninth grade, two were retained one time and two were retained twice. In contrast, 12 of 90 control group members were retained once and two were retained twice, $\mathrm{X}^{2}(2)=6.41, p<.05$. High school retention data were not available. School drop-out results also favored the bilingual treatment participants (see Table 1). Between the beginning of junior high and the 11th grade, $23.5 \%$ of the bilingual group dropped out of school compared to $43 \%$ of the control students.

\section{Analyses of Impacts of Differing Lengths of Exposure to Bilingual Programs}

A series of analysis examined the relationship between number of years in the elementary bilingual program and educational outcomes for the experimental group members. Associations between 
Table 2

Grade Point Averages of Experimental Group Members by Number of Years Enrolled in Bilingual Program

\begin{tabular}{|c|c|c|c|c|c|c|c|c|c|c|c|c|}
\hline \multirow{3}{*}{ Grade } & \multicolumn{12}{|c|}{ Number of Years in Bilingual Program } \\
\hline & \multicolumn{2}{|c|}{ One } & \multicolumn{2}{|c|}{ Two } & \multicolumn{2}{|c|}{ Three } & \multicolumn{2}{|c|}{ Four } & \multicolumn{2}{|c|}{ Five } & \multicolumn{2}{|l|}{ Six } \\
\hline & $\bar{x}$ & $N$ & $\bar{x}$ & $N$ & $\bar{x}$ & $N$ & $\bar{x}$ & $N$ & $\bar{x}$ & $N$ & $\bar{x}$ & $N$ \\
\hline 7 th grade & 1.99 & 14 & 2.28 & 25 & 2.10 & 14 & 2.56 & 10 & 2.56 & 9 & 2.51 & 11 \\
\hline 8th grade $\mathrm{a}^{\mathrm{t}}$ & 1.65 & 12 & 1.92 & 25 & 1.52 & 14 & 2.37 & 10 & 2.12 & 9 & 2.32 & 10 \\
\hline 9th grade ${ }^{a}$ & 1.42 & 11 & 1.93 & 20 & 1.71 & 13 & 2.42 & 8 & 2.02 & 9 & 2.31 & 9 \\
\hline 10th grade & 1.87 & 2 & 2.47 & 10 & 2.18 & 4 & 1.86 & 4 & 2.22 & 5 & 2.61 & ( \\
\hline
\end{tabular}

Note: Analysis of variance with linear trend contrast performed. Significance levels are for the unweighted linear trend coefficients. Two children enrolled for seven years excluded.

${ }^{\mathrm{a}} p<.05$

number of years in bilingual program and attendance and between number of years and retentions were quite weak and did not approach statistical significance at the $p=.05$ level. Important relationships, however, emerged between number of years and junior high GPA and between number of years and school dropout. As presented in Table 2, students enrolled in bilingual programs for greater amounts of time tended overall to have higher GPAs. Similarly, Table 3 shows that drop-out rates tended to decrease as number of years in bilingual programming increased.

\section{DisCUSSION}

Both the experimental-control comparison and the analysis of impacts of differing levels of exposure suggest possible beneficial impacts of the bilingual approach. The pattern of the data is particularly strong in the level of exposure analysis; students with longer exposure to bilingual programs are more apt to stay in school and to achieve better grades while they are there. These data suggest that bilingual impacts may continue through junior high and into the high school years.

The results suggest that the elementary bilingual program enabled program participants to achieve somewhat higher GPAs than the control group. Although the grade point differences were not statistically significant, the direction of findings favors the bilingual participants. The important length-of-time finding in the within bilingual group analysis merits further discussion. This 
Table 3

\section{Drop-outs for Experimental Group Members by Number of Years Enrolled in Bilingual Program}

\begin{tabular}{|c|c|c|c|c|c|c|c|c|c|c|c|c|}
\hline \multirow{3}{*}{$\begin{array}{l}\text { Level at time } \\
\text { of drop-out }\end{array}$} & \multicolumn{12}{|c|}{ Number of Years in Bilingual Program } \\
\hline & \multicolumn{2}{|c|}{ One } & \multicolumn{2}{|c|}{ Two } & \multicolumn{2}{|c|}{ Three } & \multicolumn{2}{|c|}{ Four } & \multicolumn{2}{|c|}{ Five } & \multicolumn{2}{|c|}{ Six } \\
\hline & $\%$ & $N$ & $\%$ & $N$ & $\%$ & $N$ & $\%$ & $N$ & $\%$ & $N$ & $\%$ & $N$ \\
\hline Junior High & 7.1 & 14 & 8.0 & 25 & 0.0 & 14 & 9.1 & 11 & 11.1 & 9 & 9.1 & 11 \\
\hline High School & 38.5 & 13 & 13.0 & 23 & 23.1 & 13 & 0.0 & 9 & 10.5 & 8 & 0.0 & 10 \\
\hline $\begin{array}{l}\text { Jr. High or } \\
\text { High School }\end{array}$ & 42.9 & 14 & 20.0 & 25 & 23.1 & 13 & 0.0 & 10 & 22.2 & 9 & 9.1 & 11 \\
\hline
\end{tabular}

Note: Junior high totals include all drop-outs prior to the end of ninth grade. High School totals include drop-outs through the first semester of eleventh grade. Students who dropped out in junior high were excluded from the high school analysis. Analysis of variance with linear trend contrast performed. Significance levels are for the unweighted linear trend coefficients. Two students enrolled for seven years excluded.

${ }^{\mathrm{a}} p<.05,{ }^{\mathrm{b}} p<.01$

finding refutes findings by Stern (1975) who found subjects who had been in bilingual progams the longest time were those who scored the lowest on criterion tests. Contrary to Stern, these findings support Cummins' (1979) developmental interdependence hypothesis which proposes that competence in a second language is partially a function of the degree of competence the child has developed in his/her native language at the time when intensive exposure to the second language begins. Cummins suggests that a high level of first language skills makes possible the development of similar competence in the second language. Studies by Rosier and Farella (1976), Skutnabb-Kangas and Toukomaa (1976), and Cummins (1981) have supported this developmental interdependence hypothesis. In each case it was found that learning of literacy-related skills or knowledge in the first language predicted learning and transfer of those skills in the second language (Cummins, 1981).

Our finding that students who were in the bilingual program longer outperformed those students with shorter bilingual exposure gives credence to the threshold hypotheses proposed by both Toukomaa and Skutnabb-Kangas (1977) and Cummins (1979, 1980, 1981). Cummins has suggested that it takes from four to five years of native language instruction to achieve this threshold level and our data tend to confirm this.

The issues of retention and drop-out are intertwined. The bilingual program appeared to function as an alternative to retention 
at the elementary level. As such, the bilingual participants were younger than the controls, and progressed through secondary school at more age-appropriate grade levels. The lower incidence of retentions may also have resulted in improved school attitudes and self-esteem. Further, of equal importance is the finding that the incidence of school drop-outs decreased with longer periods of enrollment in the bilingual program. This suggests that students with more exposure to bilingual education achieved what Cummins refers to as the necessary threshold (native language foundation) that is a prerequisite for competence in the second language. This suggests that students with longer periods of bilingual exposure were able to experience more success in junior and high school grade acheivement therefore they were less likely to exit from school.

In brief, influence of the bilingual experience seems to continue into junior high and high school. Students who were exposed to longer periods of enrollment in the bilingual program achieved higher grades and were less likely to become school drop-outs. The major hurdle for children whose home language is other than English is getting through elementary school. Both experimental and control subjects had difficulty with English. Students in the control group were given more time in school via retentions. The bilingual program group experienced more success in school during the important early years and were retained less. This study affirms that bilingual programs facilitate second language learning, school achievement, and are a deterrent to school dropout.

\section{Resumen}

En un estudio de tipo cuasiexperimental se comparó el funcionamiento académico a nivel secundaria y preparatoria de dos grupos de estudiantes. Los estudiantes en el grupo experimental $(N=86)$ habían recibido uno o más años de instrucción bilingüe a nivel de escuela primaria, mientras que el grupo control $(N=$ 90) no había participado en programas bilingües durante la primaria. Aunque las diferencias entre el promedio de calificaciones (GPA) y el ausentismo fueron pequenãs, los resultados indican que los estudiantes bilingües tenían menos posibilidad de abandonar la escuela y de experimentar menos retenciones. Se efectuó un análisis secundario con el grupo experimental en cuanto a la relación del número de años inscrito en el programa bilingüe y el resultado de la escuela secundaria. Las relaciones entre número 
de años y ausentismo y retención fueron bastante débiles. Sin embargo, se observaron relaciones importantes entre número de años y promedio escolar (GPA) y entre número de años y abandono de la escuela. A medida que el número de años aumentó, el promedio de calificaciones (GPA) en el $7^{\circ}, 8^{\circ}$ y $9^{\circ}$ grados tambien aumentó, y la probabilidad de que estos estudiantes abandonaran la escuela disminuyó.

\section{REFERENCES}

Anderson, T., \& Boyer, M. (1970). Bilingual schooling in the United States. Vol. 1. Washington, DC: U.S. Government Printing Office.

Barclay, L. K. (1983). Using Spanish as the language of instruction with MexicanAmerican Head Start Children: A re-evaluation using meta-analysis. Perceptual and Motor Skills, 56, 359-366.

Coleman, J. S., Campbell, E. Q., Hobson, C. J., MacPartland, J., Mood, A. M., Weinfeld, F. D., \& York, R. L. (1966). Equality of educational opportunity. Washington, DC: Office of Education, and Welfare, U.S. Government Printing Office.

Cordasco, F. L. (1983). Bilingual education: Overview and inventory. The Educational Forum 47, 321-334. (1979).

Cortez, P. G., \& Say, M. W. (1974). Bilingual education program, evaluation report, 1973-1974, fifth year of operation. Unpublished report, Houston Independent School District.

Croft, D. B., \& Franco, J. M. (1983). Effects of a bilingual education program on academic achievement and self-concept. Perceptual and motor skills, 57, $583-586$.

Cummins, J. (1977). Cognitive factors associated with the attainment of intermediate levels of bilingual skills. Modern Language Journal, 61, 3-12.

Cummins, J. (1979). Linguistic interdependence and the educational development of bilingual children. Review of Educational Research, 49, 222-251.

Cummins, J. (1980). The cross-lingual dimensions of language proficiency: Implications for bilingual education and the optional age issue. TESOL Quarterly, 4, 175-187.

Cummins, J. (1981). The role of primary language development in promoting educational success for language minority students. In Schooling and Language Minority Students: A Theoretical Framework Los Angeles, CA: Evaluation, Dissemination and Assessment Center, California State University.

Curiel, H., Stenning, W. F. \& Stenning, P. C. (1979). Achieved reading level, self-esteem, and grades as related to length of exposure to bilingual education. Hispanic Journal of Behavioral Sciences, 2, 389-400.

Danoff, M. N., Coles, G. J., McLaughlin, D. H., \& Reynolds, D. J. (1977a). Evaluation of the impact of ESEA Title VII Spanish bilingual education programs, Volume 1: Study designs and interim findings. Palo Alto, CA: American Institute of Research, (ERIC Document Reproduction Service No. ED 138-090).

Danoff, M. N., Coles, G. J., McLaughlin, D. H., \& Reynolds, D. J. (1977b). Evaluation of the impact of ESEA Title VII Spanish/English bilingual ed- 
ucation programs, Volume II: Project descriptions. Palo Also, CA: American Institutes of Research, (ERIC Document Reproduction Service No. ED 138-091).

Danoff, M. N., Coles, G. J., McLaughlin, D. H., \& Reynolds, D. J. (1978a). Evaluation of the impact of ESEA Title VII Spanish/English bilingual education programs, Volume III: Year two impact data, education process, and in-depth analysis. Palo Alto, CA: American Institutes of Research, (ERIC Document Reproduction Service No. ED 154-635).

Danoff, M. N., Coles, G. J., McLaughlin, D. H., \& Reynolds, D. J. (1978b). Evaluation of impact of ESEA Title VII Spanish/English bilingual education programs, overview of study and findings. Palo Alto, CA: American Institutes of Research, (ERIC Document Reproduction Service No. ED 154634).

Flores, D. J. (1981). An investigation of the long term effects of bilingual education upon achievement, language maintenance and attitudes (Doctoral dissertation, University of Florida, 1981). Dissertation Abstracts International, $42,1928 \mathrm{~A}$.

Fradd, S. (1982). Reading instruction for non-English speakers: When and how? Florida Reading Quarterly, 18, 35-37.

Leyba, C. F. (1978). Longitudinal study, Title VII bilingual program, Santa Fe public schools, Santa Fe, New Mexico. Los Angeles, CA: National Dissemination and Assessment Center, California State University.

Peal, E., \& Lambert, W. (1962). The relation of bilingualism to intelligence. Psychological Monographs, 76, 1-23.

Powers, S., \& Rossman, M. H. (1984). Evidence of the impact of bilingual education: A meta-analysis. Journal of Instructional Psychology, 11, 75-78.

Rosier, P., \& Farella, M. (1976). Bilingual education at Rock Point-Some early results. TESOL Quarterly, 10, 379-388.

Saldate, M. IV., Mishra, S. P., \& Medina, M. J. (1985) Bilingual instruction and academic achievement: A longitudinal study. Journal of Instruction Psychology, 12, 24-31.

Skutnabb-Kangas, T., \& Toukomaa, P. (1976). Teaching migrant children's mother-tongue and learning the language of the host country in the context of the socio-cultural situation of the migrant family. Helsinki, Finland: The Finnish National Commission for UNESCO.

Stern, C. (1975) Final report of the Compton Unified School District Title VII bilingual-bicultural project. September 1969 through June 1975. Compton City, CA: Compton City Schools.

Toukomaa, P., \& Skutnabb-Kangas, T. (1977). The intensive teaching of the mother-tongue to migrant children of pre-school age and children in the lower level of comprehensive school. Helsinki, Finland: The Finnish National Commissions of UNESCO.

Troike, R. (1978). Research evidence for the effectiveness of bilingual education. NABE Journal, 3, 13-24.

United States Department of Education, Annual Report, (1984). Office of Bilingual Education and Minority Languages Affairs: National Clearinghouse for Bilingual Education, Rosslyn, Virginia.

Willig, A. C. (1985). A meta-analysis of selected studies on the effectiveness of bilingual education. Review of Educational Research, 55, 269-317.

Received October 10, 1985

Revision received June 16,1986 